\title{
Research on Alternative Passage of Suez Canal
}

\author{
Jialu WU ${ }^{1}$, Di XU ${ }^{*}$ \\ ${ }^{1}$ Centre for Economics, Policy and Development Strategy, China Waterborne Transport Institute, 100088, No.8 Xitucheng Road, \\ Haidian District, Beijing, China
}

\begin{abstract}
The paper analyses the possible alternative routes of Suez Canal and establishes the model to decide under what conditions a container vessel should deviate from its original route. Some suggestions are proposed to help shipping companies to make decisions. The result shows that time of canal congestion is the most important factor for ships to make decisions, the blockage has great impact on Asia-Mediterranean route, and the selection time of detour is further extended considering the time value of cargo.
\end{abstract}

\section{Introduction}

On Mar 23, 2021, Suez Canal was blockage by "Ever Given" and caused the shut-down of the most important shipping route between Asia and Europe. The accident caused widespread attention and aggravated supply tension of world container shipping market. The paper aims to analyse the potential substitute channels of Suez Canal and establish a model to calculate the costs of container ships to sail from Cape Town or sail from Suez Canal. The results could provide useful reference for shipping companies and authorities to make decisions when the Canal is blocked again.

\section{Literature Review}

Igor R. ${ }^{[1]}$ analysed the sea freight traffic between Europe and Asia, and pointed out the future directions of Suez Canal expansion. Yiru $Z^{[2]}$. compared the cost of tankers by Arctic Route and traditional Suez Canal, and the results showed that small tankers are inclined to choose Northern Sea Route. Halvor S. ${ }^{[3]}$ compared the costs of bulkers by deviating from Suez Canal to Northern Sea Routes, and the results showed that summer voyage may be profitable for bulkers. Qingcheng Z. ${ }^{[4]}$ analysed the market share of railway, traditional Suez Canal voyage and Arctic routes. However, we did not see papers focusing on the cost comparison between Suez Canal and Cape Town. As a result, in this paper the authors would like to establish a model to decide during what conditions the ship should deviate from Suez Canal to other routes.

\section{Alternative Routes}

The alternative channels of Suez Canal connecting Asia and Europe mainly include Cape Town, China- Europe freight train, air channel, Arctic passage and Sumed Pipiline. The passage capacity of Cape Town is nearly infinite. The biggest impact on the existing shipping network is reflected in the increase of sailing time and voyage cost. However, if the Suez Canal is suspended for a long time, bypassing the Cape Town can meet the needs of conventional large-scale transportation between Asia and Europe. China-Europe freight train and air channel are only suitable for high value cargo transportation. The navigation of the Arctic passage is restricted by seasonality and ship technical standards. At the same time, a very important crude oil pipeline system, namely the Suez Mediterranean crude oil pipeline (Sumed Pipeline, with a total length of $320 \mathrm{~km}$ ) could be substitute of Suez Canal, which is composed of two parallel pipelines with a diameter of 42 feet. It could help European countries to import crude oil.

\section{Model Establishment}

\subsection{Mentality of Calculation}

When the canal is congested, whether to choose the alternative route depends on whether to consider the time cost of goods or not. Without considering the time cost of goods, the deviation cost mainly includes the fuel cost and the ship rent during the voyage, while the waiting cost includes the canal toll and the ship rent. Comparing the deviation cost with the waiting cost, if the deviation cost is less, the ship should sail from Cape Town. When the deviation cost is more, the ship should stay until the Canal opens again.

The two extreme scenarios include congestion at the pilot station of the Suez Canal and the ship is still near Strait of Malacca. In scenario 1, the ship will suffer the maximum deviation cost. In scenario 2 , the ship is influenced least by contrast. When the ship is in other position, the distance and cost are between the two scenarios. When congestion occurs, fuel prices, daily ship rentals, canal tolls and other data are known numbers. For ships sailing from south to north destined

\footnotetext{
$\overline{\text { * Corresponding author: xudi@wti.ac.cn }}$
} 
to Europe and the Mediterranean region, the following models are constructed to calculate the respective ship costs of deviation and wait.

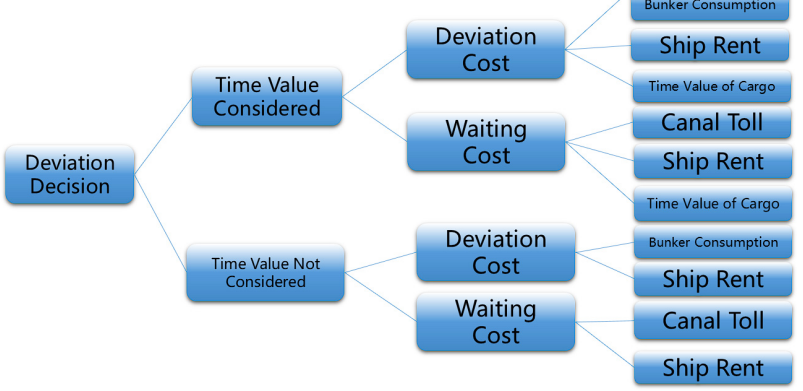

Fig 1. Mentality of the Model

\subsection{Parameters Setting}

$a$ : distance from the location sailing to Suez Canal,mile $b$ : distance from the location sailing to Cape Town, mile $t$ : time to be congested of Suez Canal, days V:ship speed, knot(mile/hour)

$C$ : ship's daily rent, USD/day

$N$ : ship's daily bunker consumption, ton/day

$P$ : bunker price for ships, USD/ton

$Q$ : State Judgement Variable, 1 denotes the Canal is still congested, 0 denotes the canal is smooth to pass $M$ :the toll charged by Suez Canal Authority, USD
$D C$ : deviation cost, the cost of ships to sail from Cape Town

$W C$ : waiting cost, the cost of ships to wait and still sail from Suez Canal

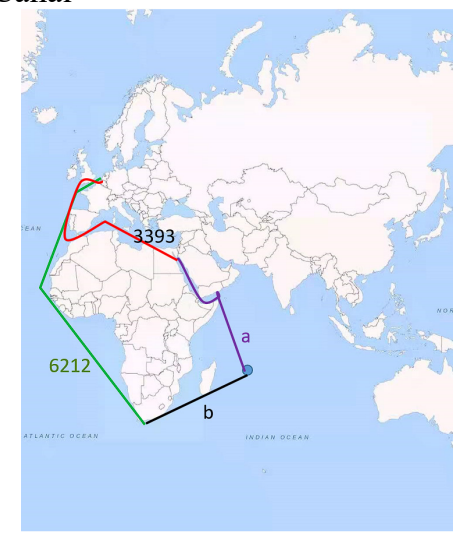

Fig 2. Route sailing from Far-east to North Europe

Suez Canal Authority is in charge of the navigation and charges of the canal. The Suez Canal charges ships with heavy load and no load. A 20000-TEU Container ship is charged on the basis of Suez Canal net tonnage (SCNT) and Suez Canal total tonnage (SCGC).

Tab 1. Charging Standard of Suez Canal ${ }^{[5]}$

\begin{tabular}{|c|c|c|c|c|c|c|c|c|c|c|c|c|c|c|}
\hline \multirow{2}{*}{$\begin{array}{l}\text { Suez Canal Tonnage/SDR } \\
\text { (Special Drawing Rights) }\end{array}$} & \multicolumn{2}{|c|}{$0-5000$} & \multicolumn{2}{|c|}{$5001-10000$} & \multicolumn{2}{|c|}{$10001-20000$} & \multicolumn{2}{|c|}{$20001-40000$} & \multicolumn{2}{|c|}{$40001-70000$} & \multicolumn{2}{|c|}{$70001-120000$} & \multicolumn{2}{|c|}{ Others } \\
\hline & Laden & Ballast & Laden & Ballast & Laden & Ballast & Laden & Ballast & Laden & Ballast & Laden & Ballast & Laden & Ballast \\
\hline Crude Tankers & 7.88 & 6.7 & 5.58 & 4.74 & 4.22 & 3.59 & 2.09 & 1.78 & 1.8 & 1.53 & 1.55 & 1.32 & 1.52 & 1.29 \\
\hline Product Tankers & 8.27 & 7.04 & 6.32 & 5.38 & 5 & 4.25 & 1.83 & 1.55 & 1.61 & 1.37 & 1.51 & 1.28 & 1.45 & 1.23 \\
\hline Containerships & 7.88 & 6.7 & 5.41 & 4.6 & 4.2 & 3.57 & 2.94 & 2.5 & 2.73 & 2.32 & 2.15 & 1.83 & 2.05 & 1.74 \\
\hline Dry Bulkers & 8.27 & 7.04 & 6.32 & 5.38 & 5 & 4.25 & 1.83 & 1.55 & 1.61 & 1.37 & 1.51 & 1.28 & 1.45 & 1.23 \\
\hline LPG & 8.27 & 7.04 & 5.99 & 5.09 & 4.43 & 3.77 & 3.6 & 3.07 & 3.15 & 2.68 & 2.94 & 2.5 & 2.94 & 2.5 \\
\hline LNG & 7.88 & 6.7 & 6.13 & 5.21 & 5.3 & 4.51 & 4.1 & 3.49 & 3.8 & 3.23 & 3.63 & 3.09 & 3.53 & 3 \\
\hline
\end{tabular}

Source: Suez Canal Authority(SCA)

\subsection{Model Establishment}

$D C=(b+6212) / 24 V^{*}\left(C+N^{*} P\right)$

$W C=(a+3393) / 24 V^{*}\left(C+N^{*} P\right)+Q *(t-a / 24 V) * C+M$

When $\mathrm{DC}<\mathrm{WC}$, the ship should deviate. In contrary, when $\mathrm{DC} \geq \mathrm{WC}$, the ship should stay or continue its voyage. And the discriminant is as follows.

$$
(b-a+2819) / 24 V^{*}\left(C+N^{*} P\right)<Q^{*}(t-a / 24 V) * C+M
$$

Given a certain location in Indian ocean, the number of $\mathrm{a}$ and $\mathrm{b}$ are known. During certain periods, ship $\operatorname{rent}(\mathrm{C})$, bunker $\operatorname{cost}(\mathrm{N})$, bunker $\operatorname{cost}(\mathrm{P})$ and the toll of Suez Canal(M) are all set, and the major variable is the congestion time. So we will introduce 3 locations, that is Suez Canal Pilot Station, Mandeb Strait and Strait of Malacca.We will calculate the results of the different intervals of rational decision making.

\section{Calculation Results}

Considering the economy of cargo value loaded on the ship, the cost of deviation will increase. The following discussion focuses on the situation of not considering the value of ship's cargo.

\subsection{Containerships sailing from Far-east to North Europe}

When the ship has arrived at the Suez Canal, and the congestion time is less than 20 days, the ship should stay to wait for the re-open of the Canal; When the ship has arrived at Mandeb Strait, the congestion time less than 2.6 days has no impact on the voyage. If the congestion exceeds 11 days, it is recommended to deviate around the canal and wait for 6 days at most; When the ship is located in the Strait of Malacca, it is recommended to sail through Suez Canal. The above is the case that only 
single ship decision is considered. In practice, due to the fact that the ships destined for northern Europe and the Mediterranean are mixed loading, the Suez Canal is still chosen.

\subsection{Containerships sailing from Far-east to Mediterranean Region}

When the ship has arrived at the Suez Canal, and the congestion time is less than 15 days, the ship should stay to wait for the re-open of the Canal; When the ship has arrived at Mandeb Strait, the congestion time less than 2.6 days has no impact on the voyage. If the congestion exceeds 12 days, it is recommended to deviate around the canal and wait for 10 days at most; When the ship is located in the Strait of Malacca, the ship can wait at most 22 days.

Tab 2. Waiting and Deviation Decisions during Suez Canal Blockage

\begin{tabular}{|c|c|c|c|c|c|c|}
\hline Route & $\begin{array}{c}\text { Vessel } \\
\text { Size(TEU) }\end{array}$ & Location & $\begin{array}{l}\text { Time } \\
\text { Intervals } \\
\text { Of No } \\
\text { Influence } \\
\text { On the } \\
\text { Vessel (Days) }\end{array}$ & $\begin{array}{l}\text { Time } \\
\text { Intervals } \\
\text { to wait } \\
\text { (Days) }\end{array}$ & $\begin{array}{l}\text { Time } \\
\text { Range to } \\
\text { Deviate } \\
\text { (Days) }\end{array}$ & $\begin{array}{l}\text { Utmost } \\
\text { Time to } \\
\text { wait in } \\
\text { Suez } \\
\text { Canal } \\
\text { (Days) }\end{array}$ \\
\hline $\begin{array}{l}\text { Far-east to North } \\
\text { Europe }\end{array}$ & 19000 & Suez Canal & 0 & $0-10$ & $>10$ & 10 \\
\hline $\begin{array}{l}\text { Far-east to North } \\
\text { Europe }\end{array}$ & 19000 & Strait of Mandeb & $<2.6$ & $2.6-7$ & $>7$ & 5 \\
\hline $\begin{array}{l}\text { Far-east to North } \\
\text { Europe }\end{array}$ & 19000 & Strait of Malacca & & & 0 & 0 \\
\hline $\begin{array}{l}\text { Far-east to } \\
\text { Mediterranean }\end{array}$ & 15000 & Suez Canal & 0 & $0-15$ & $>15$ & 15 \\
\hline $\begin{array}{l}\text { Far-east to } \\
\text { Mediterranean }\end{array}$ & 15000 & Strait of Mandeb & $<3$ & $3-12$ & $>12$ & 10 \\
\hline $\begin{array}{l}\text { Far-east to } \\
\text { Mediterranean }\end{array}$ & 15000 & Strait of Malacca & $<7$ & $7-22$ & $>22$ & 18 \\
\hline
\end{tabular}

point for the ship to choose their best strategies under

\section{Result Analysis}

\subsection{The time of canal congestion is the most important factor for ships to make decisions}

In the cost calculation comparison, the variables that affect whether the vessel's deviation is reasonable include the canal blockage time, the vessel's daily rent (daily fixed cost), the bunker price, the speed and the mileage. If the value of cargo loaded on board is taken into account, the reasonable waiting time will be extended accordingly. When Covid-19 outbroke in the first half of 2020, causing the low price of container shipping market, there were cases sailing from Cape of Good Hope on Asia-Europe routes with the case of low fuel prices, low ship rents and low market freight rates.

When the canal could resume sailing in a short time, the fuel price was high, the ship rent was high, and the market freight rate was high, the shipping companies were inclined to wait near Suez Canal. Among these variants, the time of canal congestion is the most important variable, and other variables will not change very fast in practice.

When the canal is congested, the biggest uncertainty lies in when it can resume passage. If the time of the canal's suspension can be known in advance, the shipping company can make more accurate judgment. The following will calculate the typical routes of each type of ship, and calculate the waiting equilibrium time different scenario.

\subsection{The blockage has great impact on Asia- Mediterranean route}

For Asian countries, the congestion of Suez Canal has the greatest impact on container transportation, especially for the Far East Mediterranean region. As far east Nordic and far east Mediterranean routes are the same route, the Suez Canal should still be chosen to bear the waiting cost if the canal is expected to resume navigation within three weeks when the ship departs from the Far East. If the vessel has sailed to the Strait of Malacca, it is recommended to choose Suez Canal if the congestion time in the canal does not exceed 2 weeks. When the ship has entered the Mandeb Strait, the reasonable waiting time will be further extended to about 4 weeks.

During this accident, the congestion of Suez Canal has affected the traffic for over 10 days, and more than 20 Far East European container ships sailed via Cape Town, which is basically in line with the above calculation. The increased cost for shipping companies is small, and the transportation time is relatively controllable. 


\subsection{When the time value of cargo is considered, the selection time of detour is further extended}

When considering the time value of the goods, the endurance time of the shipping company for the canal break time is further extended. At the same time, further digestion of transport capacity after the detour increases the pressure on the shipping company to operate the fleet, so the shipping company has the priority to wait in place.

The time cost of the goods shall be multiplied by the actual increased time in the case of actual deviation or no deviation by the cost of the single box per day of the goods. When deviation occurs, the additional time is the detour time minus the original time. In case of no detour, it is equal to the waiting time of the ship in the Suez Canal area.

The results of this paper could provide some reference for shipping companies when the Suez Canal is somehow blocked again. Anyone could use the model to calculate their own reasonable waiting time.

Later, the authors will continue to perfect the model by considering the time value of goods. Also, the authors will establish the revised model and apply it to bulkers and oil tankers as well.

\section{Acknowledgements}

THE AUTHOR GRATEFULLY ACKNOWLEDGES HELP FROM MR JIA DASHAN, MR NING TAO AND OTHER PEOPLE WHO INSPIRE US TO ESTABLISH THE MODEL. WU AND XU ALSO THANK THEIR FAMILY WHO CONTINUALLY PROVIDE MUCH SUPPORT.

\section{References}

1. Igor R., Irina G. Features of Sea Freight through the Suez Canal[C]. Trans Siberia 2020 Conference (2020).

2. Yiru Z, Qiang M, Szu H.N. Shipping efficiency comparison between Northern Sea Route and the conventional Asia-Europe shipping route via Suez Canal[J]. Journal of Transport Geography. 57:241249, 2016.

3. Halvor Schøyen, Svein Bråthen. The Northern Sea Route versus the Suez Canal: Cases from Bulk Shipping [J]. Journal of Transport Geography. 19: 977-983, 2011.

4. Qingcheng Zeng, Tingyu Lu, Etc. The competitiveness of Arctic shipping over Suez Canal and China-Europe railway[J]. Transport Policy:86:34-43,2020.

5. Suez Canal Tolls Table[EB/OL]. https://www.suezcanal.gov.eg/English/Navigation/T olls/Pages/TollsTable.aspx 